\title{
DISSECTING THE CONTENTS OF LAW OF INDONESIA ON HALAL PRODUCT ASSURANCE
}

\author{
Aal Lukmanul Hakim*
}

* Lecturer of Private Law at Faculty of Law Universitas Djuanda Bogor

Article Info

Received : 21 February 2015 | Received in revised form : 28 April 2015 | Accepted : 29 April 2015

Corresponding author's e-mail : aal.lukmanul.hakim@unida.ac.id

\begin{abstract}
Indonesia with its majority Moslem population and even the biggest Moslem nation in the world has obligations to its citizens to assure the halal products (halal) for consumption and/or use as a constitutional obligation to be enforceable and applicable. The constitutional obligation is granted in the form of legal certainty covering the halalness of all products either to those useable, consumed and/or utilized by the society. Upon the legalization and enactment of Law of the Republic of Indonesia Number 33 year 2014 regarding Halal Product Assurance is the evidence of constitutionally protection commitment. Having this Halal Product Assurance Law, the people may consume and/or use any products safely, pleasantly, securely and healthy, in addition to the increase of added value for Business Entities to product and sell Halal Products. Step to be taken now is how to prepare this Halal Product Assurance Law to become an effective law applicable and acceptable either by the community, business persons, or relevant institutions, or the correlation with the international community and business persons. Whereas, the presence of this LAW-HPA will generate rahmatan lil alamin (blessing for the universe) pursuant to the Islam characteristic and behavior and not create the chaotic or difficulties in the application.
\end{abstract}

Keywords: halal, product, assurance, legal certainty, constitutional obligation

\begin{abstract}
Abstrak
Indonesia, dengan mayoritas berpenduduk Muslim, bahkan menjadi negara Muslim terbesar di dunia, memiliki kewajiban terhadap warga negaranya guna memberikan jaminan produk yang halal untuk dapat dikonsumsi dan/atau dipergunakan sebagai sebuah kewajiban konstitusional yang harus dilaksanakan. Kewajiban konstitusional tersebut diberikan dalam bentuk kepastian hukum berupa jaminan kehalalan semua produk, baik yang dipakai, digunakan, dan/atau dimanfaatkan oleh masyarakat. Disahkan dan diundangkannya Undang-undang Republik Indonesia Nomor 33 Tahun 2014 tentang Jaminan Produk Halal sebagai bukti komitmen perlindungan secara konstitusional tersebut. Dengan Undang-undang Jaminan Produk Halal ini, masyarakat dapatmengkonsumsi dan/atau menggunakan produkapapun dengan nyaman, aman, selamat, dan sehat. Juga, meningkatkan nilai tambah bagi Pelaku Usaha untuk memproduksi dan menjual Produk Halal. Langkah yang harus ditempuh adalah bagaimana menyiapkan Undangundang Jaminan Produk Halal ini menjadi sebuah undang-undang yang efektif dapat berlaku dan diterapkan serta diterima, baik oleh masyarakat, pelaku usaha, lembaga-lembaga terkait, begitu juga kaitannya dengan masyarakat dan pelaku usaha internasional. Bahwa hadirnya UU-JPH ini harus mendatangkan rahmatan lil alamain sesuai dengan sifat Islam bukan malah mendatangkan kekisruhan dan kesusahan dalam penerapannya.
\end{abstract}

Kata kunci : halal, produk, jaminan, kepastian hukum, kewajiban konstitusi 


\section{Introduction}

This article was compiled usinguses normative legal research methods, through statute approach using secondary data in the form of primary legal materials, in this case especially Law of the Republic of Indonesia Number 33 yYear 2014 regarding Halal Product Assurance. The purpose of this paper is to analyzeing the content of the Law of the Republic of Indonesia Number 33 Yyear 2014 regarding Halal Product Assurance as a form of protection of the state to its citizens, especially the Muslim community in the consumption of halal products.

Indonesia as a nation located in the Southeast Asia region is a nation with the biggest Moslem population in the world. Having such great Moslem community will surely make Indonesia have different characteristic from other nations in the implementation of its nation and state life. The implementations of the nation life in several aspects are highly affected by Islamic dogmas system as the consequence of Islamic actualization of the Indonesian people. One of them is legal and legislation system that closely related to the Islamic influences, which surely does not set aside the interest of non-Moslem society.

In relation thereto, Law of Republic of Indonesia Number 33 Year 2014 regarding Halal Product Assurance (HPA law) was enacted, which was legalized and stipulated on $17^{\text {th }}$ October 2014. This HPA law becomes a new round of protection for the society from legal uncertainty for consumption and use of various halal products, both in the form of goods and services in accordance with the obligation of Islamic laws, as the Moslem's life demands to be obligator followed, as the provision on halal and forbidden is solely the right of and authority of the Only One God (Allah S.W.T). ${ }^{1}$ Thus, the born of this HPA law is the evidence of Indonesia's commitment in fulfilling one of its constitutional obligations, which is to assure the freedom of believing in the religion and performs the religion the people adhere. This is in line with the Preambule of the Constitution of 1945 of the Republic of Indonesia. Apart from that, the obligation of the state to give protection to the halal product assurance becomes the right of the state commitment ${ }^{2}$ even it becomes fardu kifayah (religious obligation) to the State to assure the halalness of a product circulating in the market. ${ }^{3}$

As the biggest Moslem nation, it is honestly admitted that the arrangement of halal product assurance in Indonesia, that the government directly undertakes systematically and on integration basis, is moving relatively slow. In this nation, prior to the enactment of HPA law, the arrangement on the halal product assurance was still partial and overlapping. Martin Roestamy ${ }^{4}$ said that:

"Positive response to the interest of halal products assurance has been conducted by the government by issuing several rules and regulations. However, the regulations related to the certification and inclusion of halal sign is still considered partial, inconsistent, overlapping, and not systemic."

\footnotetext{
$1 *$ Lecturer of Private Law at Faculty of Law Universitas Djuanda Bogor, Bogor-16720, West Java. e-mail : aal.lukmanul.hakim@unida.ac.id

Yusuf Qardawi, Halal dan Haram Dalam Islam, edited by Mu'amalah Hamidy, (Jakarta : PT Bina Ilmu, 1993), p. 21.

2 Martin Roestamy (1), "Consumer Protection Over Meat Consumption in Accordance to Indonesian Legal System," (presented at the International Conference on Consumerism 2013 (ICC 2013). Faculty of Law UKM Malaysia, 2013), pp. 1-10.

3 Martin Roestamy (2), "The Assurance of Halal Product," (presented at the The 2013 Padjajaran International Legal Conference Series, Padjajaran University, Bandung, 2013), p. 3.

${ }^{4}$ Ibid.,
} 
The overlapping rules of halal product assurance is due to the nonexistence of certainty and obvious regulations in a basic standard issued by government, instead, the rules were contained in number of other regulations. In the meantime, the implementation of halal product assurance is only made by business persons on voluntary basis, and performed by non-government organization such as Indonesian Council of Ulemas or Majelis Ulama Indonesia (MUI) through LP-POM MUI by virtue of the Ministerial Decree of Religion of the Republic of Indonesia Number 518 Year 2001 regarding Investigation and Stipulation of Halal Food Procedures and Guidelines and Ministerial Decree of Religion of the Republic of Indonesia Number 519 Year 2001 regarding Governmental Implementing Institution for Halal Food, which endorses MUI as legal certification institution and performs the audit, stipulates a binding ruling in religious matter (fatwa), and issued halal certificate.

As a comparison, in Malaysia, the awareness of halal product assurance was started in 1982, initiated by Jawatan Kemajuan Islam Malaysia (JAKIM) by establishing the Islamic Affairs Division of the Prime Minister's Department in charge of auditing and implanting the halal consciousness amongst food producers, distributors, importers including food storage, restaurant and hotel. ${ }^{5}$ In August 2004, MS 1500:20046 (Malaysian Standard: Halal Food-Production, Preparation and Storage-General Guidelines) was launched by involving various institutions and developed based on the ISO standard and this was said as the first halal standard developed by a Moslem Nation. ${ }^{7}$

Having the legal ground, which before has not given legal certainty for halal product assurance, the halal product standardization mainly foods in Indonesia, which has been conducted by MUI and LP-POM MUI, was internationally acknowledged and became a reference of other nations to the application of halal assurance system, even Indonesia becomes the world halal center and halal certificate of MUI is acknowledged all other the world. ${ }^{8}$

The presence of HPA law will be corroborating and underlining Indonesia as a nation having the biggest Moslem population that has provided assurance to its community with legal certainty in the consumption and use of the halal products as the Moslem rights requirement but not overriding the interest of non-Moslem community. This HPA law was born as the commitment of the nation to guarantee any of religion adherents to perform their religious services and religion dogmas, and the nation is obliged to give protection and assurance of halalness of Product consumed and use by the community. The assurance of Halal Product is given pursuant to the principles of protection, justice, legal certainty, accountability and transparency, effectiveness, efficiency and professionalism as well. Therefore, the implementing assurance of Halal Product is intended to contribute the pleasant, security, safety and certainty of Halal Product availability to the community in the consumption and use

${ }^{5}$ Zakiah Samori, Amal Hayati Ishak and Nurul Himmah Kassan, "Understanding the Development of Halal Food Standard: Suggestion for Future Research," International Journal of Social Science and Humanity Vol. 4 No. 6 (November 2006): 483, doi: http://dx.doi.org/10.7763/IJSSH.2014.V4.403.

${ }^{6}$ This Malaysian Standar (MS 1500:2004) is the first revision of Malaysian Standard, MS 1500:2000 regarding Halal Food - Production, Preparation, Handling And Storage - General Guidelines. This standard was issued by Departement of Standards Malaysia as Malaysian standarisation and accreditation body. See, http://www.standardsmalaysia.gov.my/

7 Samori, loc.cit.

8 LP-POM MUI (1), "Recomendation International Workshop: Indonesias Role for Slaugthering Global Halal," http://www.halalmui.org/newMUI/index.php/main/detil_page/8/538, 2014, accessed 25 November 2014. 
of products, and increase of added-value for the Business Persons to produce and sell Halal Product (general explanation of HPA law). Thus, other than protecting the community in the consumption and use of products, which the halalness is secured, this HPA law also halalhas multipliers effect to the industry, for example, encouraging the opening of business opportunities in halal products which have promising and prospective opportunities.

As the portrayal to find out on what a big halal product market opportunity is, can be seen from the big Moslem market which covers US\$ 2 trillion. That number shows that Moslem market is one of consumer segments with the fastest growth in the world. The halal culinary market contributes $12 \%$ of the world food trade, approximately about US $\$ 560$ billion, ${ }^{9}$ and this keeps growing for $20-30$ percent annually ${ }^{10}$ and Indonesia contributes about 180 billion. In addition, the halal market segment involves more than two billion Moslem population in the world and distributed in more than 112 nations. ${ }^{11}$

Currently, halal is not solely the issue of certain religion, but also extended to the scope of businesses and considered as well as a global symbol in securing the quality and selecting the lifestyle. Likewise, nowadays, halal is not merely intended for Moslem, in several countries such as Thailand, United Kingdom, and United States of America, which Islam is not considered as the official religion of the countries, encourage the productions in their countries to be based on the Islamic Law and to have commitment to respect the halal product upon religion standard as halal labels produce high capital economy halaland increase consumers' interest in the products. $^{12}$

Along with the relatively fast growth and wide opportunity, Indonesia needs to provide legal umbrella with respect to this halal product, which is expected to protect the consumers halally (rightfully), but not limited thereto. Even producers are also automatically protected and the halal market will be more growing. As the biggest Moslem country, Indonesia has great opportunity, not only as the biggest halal consumers market segment, but also has opportunity to be halal product producers. Those opportunities are enormously and widely opened. Moreover, by the presence of HPA law, a halal product certification is an obligatory for business persons, as stated in Article 4 of HPA law.

\section{Law of Republic of Indonesia Number 33 Year 2014 Regarding Halal Product Assurance (Law-HPA)}

\section{A. Ratio of Legis Law-HPA}

As explained previously, the enactment of HPA law is the form of freedom of every people to believe in a religion and perform the religion in line with their religion and belief, as also set forth in Article 29 paragraph (2) of Constitution of 1945 of the

${ }^{9}$ SPRING Singapore, Global Halal Food Industry Guide to Taping the Fasat Growing Halal Food Market (Singapore: SPRING Singapore, 2011) , p. 6.

10 E. S. Soesilowati, "Business opportunities for halal products in the global market: Muslim consumer behaviour and halal food consumption," Journal of Indonesian Social Sciences and Humanities Vol. 3 (January 2010): 151.

${ }^{11}$ Asadollah Kordnaeij, Hossein Askaripoor, and Alireza Bakhshizadeh, "Studying Affecting Factors on Customers' Attitude toward Products with Halal Brand," International Research Journal of Applied Basic Sciences Vol. 4(10) (2013): 3138.

12 Ibid. 
Republic of Indonesia. One of the warrants to perform a religion is assurance of halal product consumption and use, as this is a law applied to Islam followers. While Islam requires its adherents to consume halal products, in fact, not all products circulating in the community are securely halal since there was no legal obligation imposed on producers to state whether their products are produced from permitted (halal) materials to be consumed and/or used by the community.

With respect to the certified halal product, until 2014, the Institute for Foods, Drugs, and Cosmetics Indonesian Council of Ulama / Lembaga Pengkajian Pangan Obat-obatan dan Kosmetika Majelis Ulama Indonesia (LPPOM-MUI) issued around 3.708 Halal Certificates for 121.508 products and only 3.123 companies or business persons have made halal certification for their products, ${ }^{13}$ and of the amounts, the certification is made voluntarily, this means the certification is made based upon the request of business persons, not as a legal obligatory imposed on them. Whereas based on the data of Center for Statistic Agency (BPS) of 2010-2011, for big food industries, there are about 5.777 industries, and in 2013 rose to be 5.832 industries. ${ }^{14}$ It seems that the ratio of business persons and the certification quantity is imbalanced; this is caused by the absence of legal obligatory imposed on the business persons to make halal certification.

In the efforts to give assurance to the community in the consuming and using halal products, the Indonesian government, in October 2014 issued the Law Number 33 Year 2014 regarding Halal Product Assurance.

HPA law mentions that a Product means goods and/or services with respect to foods, drinks, drugs, cosmetics, chemical products, biological products, genetically engineered product and used utility, used and utilized by the community. The law also statelaw also states that a Halal Product is a product that has been stated halal based on the Islamic Law.

In the Islamic law, a halal product is something to be consumed and used, and those which not permitted to be consumed or used shall be considered as forbidden product. With respect thereto, Yusuf Qardhawi said that the originality of things created by God is halal and neither forbidden nor required. Nothing is forbidden, except as there is authoritative and strict quotation of syari' (those authorized to make the law, namely Allah and the Apostle) who forbid them. ${ }^{15} \mathrm{Al}$-Jurani in his book at-Ta'rifat states that halal is an ability to use something for the fulfillment of physical need, including foods, drinks and drugs. In general, halal is permission to eat, drink and do something based on Islam Law and the principles. Halal is a universal term applicable to all life aspects. ${ }^{16}$ This halal standardization is set and specified in AlQuran, Sura Al-Baqarah verse: $172-173$ citing: ${ }^{17}$

o you who have believe, eat from the good things We have provided for you and be grateful to Allah if it is (indeed) Him that you worship; He has only forbidden to you dead animals, blood, the flesh of wine, and that which has been dedicated

13 LP-POM MUI (2), "Rekapitulasi Sertifikat Halal Tingkat Nasional," http://www.halalmui.org/ mui14/index.php/main/go_to_section/59/1368/page/1, accessed 26 January 2015.

${ }^{14}$ Badan Pusat Statistik (1), "Jumlah Perusahaan Industri Besar Sedang Menurut Sub Sektor 20082013," http://www.bps.go.id/tab_sub/view.php?tabel=1\&daftar=1\&id_subyek=09\&notab=2, accessed 26 January 2015.

15 Qardawi, op.cit., p. 17.

16 Samori, op.cit., p. 482.

17 King Saud University. (n.d). Alquran Digital 'Ayat', . version 1.3.2. 
to other than Allah. But who ever is forced (by necessity), neither desiring (it) nor transgressing (its limit), there is no sin upon him. Indeed, Allah is Forgiving and Mercyfull.

Hence, consumption and/or use of halal product for Moslems are obligatory directly correlated to the one's religiousness; accordingly it affects the person's behavior in the consumption pattern.

Moreover, for a Moslem, consuming halal product means more than his faithfulness materialization to Allah only, but also is believed as a grant and an answer of his pray; it prevents him from hell, from illness and following Satanic steps. ${ }^{18}$ Seeing that the halal becomes something which has theology aspects, Indonesia, sociologically as the world's largest Muslim country deserved to have a law that governs the halalness of products circulating in and among the community. Notwithstanding, a Moslem wherever he is, will keep seeking for halal product for consumption and use.

In a study, Arshia Mukhtar and Muhammad Mohsin Butt ${ }^{19}$ conclude that:

"Muslims in these countries are conscious and have a very positive attitude towards Halal products that positively influences their intention to purchase those products. Furthermore, their attitudes are heavily influenced by subjective norms. Thus, it indicates the role of Muslim societies in dictating such attitudes. Further, it is said, it is not surprising to witness that food, cosmetics and pharmaceutical brands are facing the brunt of Muslims consumers' skepticism. Thus, it is obvious that the presence of HPA law in Indonesia becomes a positive barrier in the effort to protect the community from forbidden products to be consumed and/or used, which shall have halal or forbidden history clarification of the products.

The clarification and assurance of a product's ingredients or processing as halal or forbidden become so crucial and relevant if it is related to the technology advancement in foods, drugs, cosmetics, which effects the production processing system of foods, drugs, cosmetics and other products. With the technology advancement, it is not impossible that in the production process, which substantial is halal, is mixed with and/or contaminated by forbidden (haram) raw materials. Having the HPA law been enacted as the basic norms of arrangement on how a product should be produced and finally distributed to end-users, this provides assurance to the consumers, especially to Moslems for consumption and/or use of safe and pleasant product and will surely have good impact on health.

In the general explanation of HPA law, it mentions the principles arrangements, which is as follows:

a. To secure Halal Product availability, the product materials are specified and stated halal, either material is from animals, plants, microbe, or materials produced from chemical processing, biological processing or genetically engineered processing. In addition, the Halal Product Process as the range of activities shall also be specified to guarantee the halalness of Product covering the supply of materials, treatment, storage, packing, distribution, selling and presentation of products.

${ }^{18}$ Ahmad Sarwat, Halal Atau Haram : Kejelasan Menuju Keberkahan (Jakarta: PT Gramedia Pustaka Utama), pp. 2-5.

19 Arshia Mukhtar and Muhammad Mohsin Butt, "Intention to Choose Halal Products: The Role of Religiosity," Journal of Islamic Marketing Vol. 3 Issue 2 (2012): 116, doi: http://dx.doi. org/10.1108/17590831211232519. 
b. This Law sets the right and obligation of Business Persons with exception given to the Business Persons producing the Products made of forbidden materials with their obligation to put strictly the forbidden notice on the Product package or on certain viewable, readable part of the product, and not easily erased or deleted and constituted in inseparable part of the Product.

c. In the framework of rendering public services, Government is responsible for performing HPA, which implementation shall be made by Implementing Body of Halal Product Assurance (IBHPA) or Badan Penyelenggara Jaminan Produk Halal (BPJPH). In the performance of its authority, IBHPA will collaborate with the relevant ministries and/or institutions, MUI, and Halal Auditor Institution (HAI) or LPH (Lembaga Pemeriksa Halal).

d. The submission procedures of Halal Certificate are initiated with the filing of application for Halal Certificate by a Business Person to IBHPA. Next, IBHPA will audit the completeness of documents. The audit and/or examination of halalness of product will be conducted by HAI. The HAI must obtain the accreditation from IBHPA in collaboration with MUI. The stipulation of halalness of a Product is made by MUI at and through halal binding ruling session of MUI to adopt the decision on the Stipulation of Halal of Product to be endorsed by MUI. IBHPA issues the Halal Certificate based on the decision on the Stipulation of Halal of Product by.

e. Cost of halal certification will be charged to the Business Person which submits the application for Halal Certificate. For a smooth operation of halal product assurance implementation, this Law provides the role to another party such as Government through the State Budget, regional government through its regional budget, company, social institution, religion institution, association, and community to facilitate halal certificate cost for micro and small-scaled business persons.

f. In the framework of securing the implementation of halal product assurance operation, IBHPA shall supervise the HAI; the validity period of Halal Certificate; halalness of Product; inclusion of Halal Label; inclusion of non-halal statement; separation of location, place and processing instrument, storage, packing, distribution, selling, and presentation of Halal Product and non-halal Product; the existence of Halal Supervisor; and/or other activities with respect to the halal product assurance.

g. Toguarantee the legal enforcementagainst the violation of this Law, administrative and criminal sanction shall be stipulated.

Upon the enforcement of this HPA law the Moslem community in Indonesia is protected in their own country in consuming circulating products. However, the arrangement of halal product in a law is not meant to set aside the interest and protection of non-Moslem consumers. The presence of this HPA law does not necessary mean that all products circulated and marketed in Indonesia have to and absolutely must be halal products and therefore forbid non-halal product circulation. This HPA law also protects non-Moslem consumers by giving priority to the justice principles, this means that in the implementation of halal product assurance it must reflect the fairness proportionally to all citizens. This is evidenced that in this HPA law any products made of forbidden-materials may remain circulated and marketed but also non-halal description should be included. That is to sayIn conclusion, with 
this LAW-HPAHPA law does not mean the food which is prohibited for Muslims (but can be consumed by people of non-Muslim) should not be circulated, but still be able to be circulated. tThus, herein lies the proportional fairness provided by this law with due regard to the interests of the non-Muslim communities. The LAWHPAHPA law protects Moslem consumers and also gives protection to non-Moslem consumers as the halal product is a universal concept, not only for Moslem, but also accepted by anybody. It makes sure that if a product is stated halal, then the product will surely have good effect on the users, whoever they are, as this is assurance from Allah. Accordingly, this HPA law determines that any imported products, which are circulated and traded in Indonesia territory, must have halal certificate pursuant to the Article 4 of HPA law.

\section{B. Implementation of Halal Product Assurance}

An institution in charge of halal product assurance processing is established in the implementation of halal product in Indonesia through this HPA law, namely, the Implementing Body of Halal Product Assurance (IBHPA), which is responsible for assuring all products, goods and/or services with respect to foods, drinks, drugs, chemical products, biological products, genetically engineering product, and utility goods, used or utilized by the community are halal pursuant to the Islam Law. In the performance of its tasks and functions, IBHPA is under coordination of minister in charge of religion affairs, in this case Minister of Religion of the Republic of Indonesia.

In implementing halal product assurance, IBHPA has the authority of:

a. Formulates and specify halal product assurance policy;

b. Stipulates the norm, standard, procedure and criteria of halal product assurance;

c. Issue and revoke Halal Certificate and Right Label on the Product;

d. Makes registration of Halal Certificate to overseas-made Products;

e. Makes socialization, education and publication of Halal Product;

f. Makes accreditation to the Halal Auditor Institution (HAI);

g. Makes registration of Halal Auditor;

h. Makes supervision to halal product assurance;

i. Makes Right Auditor development; and

j. Makes cooperation with national and international institution in the area of halal product assurance implementation.

IBHPA, in the technical implementation of halal product assurance in auditing and/or examining a product, shall cooperate with ministry and/or institution, Halal Auditor Institution and Indonesian Council of Ulama or Majelis Ulama Indonesia (MUI). LAW-HPA provides MUI a privilege as an institution having authority to make halal auditor certification, to stipulate the halalness of a product, and accrediting Halal Auditor Institution. This privilege given to MUI is understandable as a professionalism form adhered by this HPA law, as before the enactment of this HPA law, MUI has become an institution to perform the Halal certification in Indonesia, which the certification standard is internationally acknowledged and even Indonesia becomes a Global Halal Center. Upon the professionalism experience, the HPA law appoints MUI as an institution having such privilege.

Furthermore, LAW-HPA specifies that auditing and/or examining the halalness of 
a product shall be done by a Halal Auditor Institution (HAI), which can be established either by government or by community provided that: (a) it has office and the auditing equipment; (b) it has accreditation issued by IBHPA; (c) it has minimum 3 (three) Halal Auditors; and (d) it has laboratory or cooperation agreement with another institution having the lab. From this HAI, the Halal Auditor will be assigned to:
a. Audit and analyze the materials in use;
b. Audit and analyze product treatment process;
c. Audit and analyze slaughtering system;
d. Examine the product location;
e. Examine the equipment, production room and storage area;
f. Check the product distribution and presentation;
g. Audit the halal assurance system of the Business Person; and
h. Report the audit results to HAI.

\section{Materials and Processing of Halal Product}

Materials processed to be finished products shall be segregated as raw materials, processing material, additional materials and auxiliary materials, which are derived from: animal, plants, microbe, or materials produced through chemical processing, biological processing, or genetically engineering process. Particularly for raw material made from animals, the HPA law specifies all materials of animal principally are halal except those forbidden pursuant to the article 17 paragraph (3) of LAW-HPAHPA law. This shows that the provision of this HPA law is in line with the Islam ritual obligation norms, which specify that the principle law of all objects is halal except those strictly are forbidden by law.

The LAW-HPA reconfirms the materials of forbidden animals in Article 18 paragraph (1) which is based upon the Al-Qur'an verses of Sura Al-Baqoroh verse: 173, namely:
a. Carcass;
b. Blood;
c. Pork; and/or
d. Animal slaughtering beyond the law (shariah).

HPA law requirement of the slaughtering of animals is not only pursuant to the Islam law, but also to fulfill the animal welfare norms and veterinary community prosperity. The animal welfare is as set out in Law of Republic of Indonesia Number 18 Year 2009 regarding Husbandry and Animal Health, and in Government Regulation of Republic of Indonesia Number 95 Year 2012 regarding Veterinary Community Health and Animal Welfare.

In the meantime, materials made of plants, the HPA law specifies that all plants principally are halal, except those causing intoxication and/or perilous to the health of persons consuming them. And materials made of microbe and materials produced from chemical processing, biological processing or genetically engineering processing are forbidden if the growth and/or manufacturing processing are mixed, contained, and/or contaminated with forbidden materials. 
As the phenomenon of professionalism principle in this HPA law, the halal or forbidden status of all materials shall be specified by Minister based on the Bind Ruling of MUI.

With respect to the halal product processing as one of crucial and decisive links of halal product, HPA law requires that the location, place and processing of halal products shall be separated from location, place and slaughtering equipment, treatment, storage, packing, distribution, selling and presentation of non-halal products. Thus, the halal product location, place and processing shall be kept hygiene; free from excrement and free from non-halal materials. The business persons or producers who fail to make the separation shall be imposed on administrative sanction covering written warning and administrative penalty.

Based on the provision of HPA law regarding material and processing of a halal product, it is seen that high prudence is demanded for all pertaining to the process, and this is the unique of halal in Islam. According to Abdul Hafaz Ngah, ${ }^{20}$ halal is obvious and details, as there is a hadits (deeds of Prophet Mohammad) says that there is clear-cut different between halal and haram (forbidden). In the framework of maintaining the halalness of a product, the product must be handled by a right man applying the right process. In the event of transportation, for example, all products are not only united in the same transportation to be moved to the right destination without considering the halal status of the product. Should there be any omissions; the halal integrity of a product can be questioned. Moreover, the Prophet does not only curse those who drink intoxicated drinks but also those who produce them, serve them, one for those they serve, one for price they pay, and so on. ${ }^{21}$

\section{Business Persons}

One of the elements in the halal product assurance system is that the business persons have the balanced right and obligation with due observance to the principles of justice, accountability, transparency, professionalism. Business persons are entitled to obtain information, education and socialization on halal product assurance system, development and right to get served for obtaining Halal Certificate on a fast, efficient, good price and non-discriminative basis.

Likewise the business persons are required to provide accurate, clear and fair information in relation to the halal certificate, separation of location, materials and halal product and non-halal product, and any business persons are obliged to have skillful supervisor on halal knowledge in every halal product processing they produce.

Business persons who have obtained the Halal Certificate are required to include halal labels on the certified products, keep the halalness, keeps separating the location, place and slaughtering system, processing instrument, storage, packing, distribution, selling, and presentation of Halal Product and Non-halal Product, and surely extend or renew the Halal Certificate if the validity period has expired. Sanction to this violation covers written warning, administrative penalty and revocation of halal certificate.

20 Abdul Hafaz Ngah, Yuserrie Zainuddin and Ramayah Thurasany, "Barriers and Enablers in Adopting Halal Transportation Services: A Study of Malaysian Halal Manufacturers," International Journal of Business and Management Vol. II No. 2 (2014): 52.

21 M. S. Ab Talib, and M. R. Mohd Johan, "Issues in halal packaging: a conceptual paper," International Business and Management Vol. 5 No. 2 (2012): 97, doi: http://dx.doi.org/10.3968\%2Fj. ibm.1923842820120502.1080. 
On the contrary, to any business persons producing product made of nonhalal materials are excluded from submission the application for Halal Certificate. Therefore, business persons are required to include information on non-halal labels on their products. If this provision is disobeyed, they will be imposed on administrative sanction covering oral warning, written warning and administrative penalty.

\section{E. Halal Certification}

Halal certification is initiated by submitting a written application of a business person to IBHPA, which cost thereof is borne by the business person, except if the business person (the applicant) is a micro and small-scaled business entity (Usaha Mikro dan Kecil Menengah/UM-KM). In that situation, the cost of Halal Certification can be facilitated by another party among other things by Government through the State Budget, regional government through the regional budget, company, social institution, religion institution, association and community.

Further, IBHPA assigns a Halal Auditor Institution (HAI) to audit and/or examine the halalness of a product. Then, the assigned auditor of HAI performs the audit and/ or examination of halalness of product made in the business' location at the time of production is being processed, and if there is any material make the halalness is doubted, then the lab test will be made. Therefore, it is the obligation of the business persons to provide accurate information to the auditor.

After the audit and/or examination, HAI will deliver the audit results to IBHPA, and IBHPA will submit the results to MUI for approval to get halalness of product, in the period of 30 (thirty) working days. The stipulation process of halalness of product by MUI is done in a halal bind ruling session attended by the experts, elements of ministry/institution, and/or relevant institutions. After the resolution is adopted, the stipulation of halalness of product is communicated to IBHPA for issuance of Halal Certificate. If the MUI Session states that the audited/examined product is not halal, IBHPA shall return the application for halal certification to the business person and the reasons thereof. The halal certificate is based upon the stipulation of MUI and issued by IBHPA to be mandatorily published, as specified in Article 35 of HPA law.

After obtaining the halal certificate for their product, the business person is required to include halal label on the product package, on certain part of the product, and/or certain place of the product. The inclusion of Halal Label must be viewable and readable and hard to delete, disengage and damaged.

The inclusion of this halal label becomes so important, which relates also to the inclusion of halal logo. Having this halal label and halal logo, in the opinion of Mohamed Syazwan Ab Talib and Mohd Remie Mohd Johan:22

"...will single-handedly influence the buying decision for Halal food products. This is because Halal logo does not only indicate that foods sold or prepared are in line with Shariah law, it also indicates that the food products are wholesome, clean and healthy."

The halal Certificate is applicable for the period of 4 (four) years as of the issuance date by IBHPA, except if there is any change of composition of materials to the product. Changing the composition of materials requires the business person to report it to IBHPA within 3 (three) months before the validity term of halal certificate expires, the

\footnotetext{
${ }^{22}$ Ibid., p. 96.
} 
business person shall submit the application for the extension.

HPA law also specifies the obligation to any person engaged in the implementation of halal product assurance process to keep the formula confidential included in the information given by the business person. And any person disclosing the confidential formula to any third party based this HPA law is threatened with imprisonment sentence for the maximum 2 (two) years or penalty at maximum Rp. 2,000,000,000.00 (two billion rupiah). This is done to protect the confidentiality of the business person.

\section{F. Internationalization}

As mentioned earlier, currently the halal matter is not only an issue in Islamic countries or in countries with majority of Moslems population, but the halal has become a global issue penetrating the boundaries of all nations, and in any religion whatsoever the people of the nation believes in as the halal constitutes a universal concept, which essentially is intended for all peoples. Therefore, the handling of halal issues is not only made nationally but also globally by developing internationalcooperation. One of the real acts is Indonesia is considered as a Global Halal Center for its proper capacity to be specified to be the pilot project of halal issue development in the world.

In relation thereto, HPA law opens a very wide opportunity for Indonesia government to make international cooperation in the halal product assurance covering the development of halal product assurance, assessment to the appropriateness, and/ or acknowledgement to the Halal Certificate.

The HPA law constitutes barrier in the effort to protect consumer to consume and/or use the product, either domestic or overseas products. This is very important to do since Indonesia becomes a high consumer nation using food products, drinks, drugs, cosmetics and so on that any imported products are not surely halal secured, moreover, products imported from non-Moslem countries.

Based on the data of Center for Statistic Agency in 2010-2013, the import value of foods and living animals reached 22,055,500 tons, fat and animal and plants oil reached 157,300 tons, and chemical substances reached $18,286,700$ tons. ${ }^{23}$ The Agriculture Quarantine Agency recorded the import realization as per October 2014 for imported meat (beef) was 76.125 tons and innards were 7.340 tons. $^{24}$

Based on the data above, Indonesia is still a big market especially for imported meat consumptions. This situation requires preventive measures to ensure the halalness of products imported into Indonesiahalal. As for the anticipation step, the HPA law equalizes the treatment of all imported products with treatment to local products and the imported products shall comply with the HPA law.

The application for the halal certificate for any imported halal products should be unnecessarily submitted to the extent that the halal certificate is issued by international halal institution having mutual acknowledgment cooperation, and the

${ }^{23}$ Badan Pusat Statistik (2), “Nilai Ekspor Dan Impor Menurut Golongan SITC, 2010-2013,” http:// www.bps.go.id/tab_sub/view.php?kat=2\&tabel=1\&daftar=1\&id_subyek=08\&notab=5, accessed 26 January 2015 .

24 Bisnis.com. "Surplus Daging Impor : Peternak Lokal Tak Berdaya," http://industri.bisnis.com/ $\mathrm{read} / 20141120 / 99 / 274447 /$ surplus-daging-impor-peternak-lokal-tak-berdaya, accessed 26 January 2015. 
halal certificate of international institution must be registered by IBHPA. Otherwise, the business persons will be imposed on administrative sanction of withdrawal of products from the market.

LP-POM of MUI, as the institution making the halal certification in its trip has made and entered into cooperation with halal certification in many other nations, which in turn would be a reference to the preparation of implementing rules of HPA law. Globally, the number of Halal Certification Institutions is: 39 Institutions from 23 Nations. Slaughtering Category: 31 Institutions, Food Processing Category: 32 Institutions, Flavor Category: 14 Institutions. Those Halal Certification Institutions are from Asia region, Australia, New Zealand, USA, and Latin America. ${ }^{25}$

\section{G. Supervision, Role of Community and Criminal Sanction}

Supervision contained in the HPA law is a supervision conducted by IBHPA to the halal product assurance to:

a. Halal Auditor Institution;

b. Validity period of Halal Certificate;

c. Halalness of Product;

d. Inclusion of Halal Label;

e. Inclusion of non-Halal label;

f. Separation of location, slaughtering place and instrument, processing, storage, packing, distribution, selling and presentation of Halal Products and non-Halal Products;

g. Presence of Halal Supervisor; and/or

h. Other activities with respect to the Halal product assurance.

Supervision to the Halal Product among other things is the supervision to the validity period Halal Certificate, inclusion of Halal Label and non-Halal notice, and presentation of Halal Products and non-Halal Products.

Other than supervision conducted by IBHPA together with the relevant ministry and/or institution having the authority thereto, in the HPA law, the community is provided with role covering socialization of halal product assurance and supervises the Products and non-Halal Products in the market. The participation of the community covering the supervision of Products and Halal Products in the market is any complaint or reporting delivered to IBHPA. This is specified in Article 53 of HPA law.

Legal certainty with respect to the halal product in the HPA law is said complete upon the rule out of two actions categorized as criminal act. In this HPA law, there are two articles specifying criminal sanction threatened, namely Article 56 and 57. Each of threats governs the Business Persons who fail to maintain the halalness of Product after having obtained the Halal Certificate and any Person involved in the implementation of halal product assurance process who fails to keep the confidentiality of product formula. The Article 56 and 57 specifies as follows:

25 LP-POM MUI (3), “Daftar Lembaga Sertifikasi Halal," http://www.halalmui.org/mui14/index. php/main/go_to_section/7/36/page/1, accessed 26 January 2015. 


\section{Article 56 :}

Business Person who fails to maintain the halalness of Product having obtained the Halal Certificate set out in Article 25 letter $b$ will be sentenced imprisonment for criminal act as charged at the longest 5 (five) years or penalty in amount of Rp2,000,000,000.00 (two billion rupiah).

\section{Article 57:}

Any person involved in the implementation of halal product assurance process who fails to keep the confidentiality of product formula given by the business person set out in Article 43 will be sentenced imprisonment for criminal act as charged at the longest 5 (five) years or penalty in amount of Rp. 2,000,000,000.00 (two billion rupiah).

Having such criminal sentence threat, the goodwill of business persons to keep its product quality as the halal product is required by this HPA law. Thus, since the enactment of this HPA law, the business persons are expected to increase the quality control of their products.

\section{III.Conclusion}

Law on Halal Product Assurance constitutes a real step made by the Indonesian Government in the realization of protection to all people of Indonesia and as an effort to guarantee the pleasant, safety, security and certainty of Halal Product availability to be consumed and used by the community, and to increase the added-value for business persons to produce and sell Halal Product, which consistently relies upon justice principle without eliminating the rights of non-Moslem community. In principal, a halal product is an applicable universal concept and is useable by all persons. Upon the halal labeling on a producthalal, the product is guaranteed to be safe and health to be consumed and/or used by anybody.

Further step is how to prepare this HPA law to become an effective law applicable and acceptable either by the community, business persons, relevant institutions, or the correlation with the international community and business persons. Whereas, the presence of this HPA law will generate rahmatan lil alamin (blessing for the universe), pursuant to the Islam characteristic and behavior. The presence of HPA law will not create the chaotic or difficulties in the application. Therefore, positive role of all relevant stake holders is highly needed. Moreover this HPA law mandates, within at the latest 3 (three) years as from the enactment date, IBHPA as a central institution for halal product assurance system in Indonesia, must have been established. Apart from that, the implementing rules of HPA law shall be stipulated at the longest within 2 (two) years as of the enactment date of this HPA law. And, the obligation of halal certificate for products circulated and traded in the territory under this HPA law shall come to effect for 5 (five) years as of this LAW-HPA is enacted.

On the other words, IBHPA must be established at the latest on October 2017, the implementing rules such as Presidential Ordinance, Ministerial Ordinance and Government Regulation must be passed and stipulated at the latest on October 2016. Finally, in 2019, all products circulated in Indonesia must have been halal certified despite of the certification is made periodically in accordance with mandate of this HPA law. This is not an easy work to do. It needs concentration, will, cooperation, coordination, and intensive silaturahim (good relationship) to all parties, government, 
relevant institutions such as MUI, LP-POM, business persons, consumer community, and all relevant parties even including high education institutions (university) to synergize to welcome new era of Indonesia as Halal Country, Insya Allah (If Allah wills).

\section{Bibliography}

\section{Legal Documents}

Indonesia. Undang-Undang tentang Jaminan Produk Halal (Law regarding Halal Product Assurance). UU No. 33 Tahun 2014, LN No. 295 Tahun 2014 (Law Number 33 Year 2014, SG No. 295 Year 2014).

\section{Books}

Qardawi, Yusuf. Halal dan Haram Dalam Islam. Edited by Mu'amalah Hamidy. Jakarta: PT Bina Ilmu, 1993.

Sarwat, Ahmad. Halal Atau Haram: Kejelasan Menuju Keberkahan. Jakarta: PT. Gramedia Pustaka Utama.

\section{Articles}

Ab Talib, M. S. and M. R. Mohd Johan. "Issues in halal packaging: a conceptual paper." International Business and Management Vol. 5 No. 2 (2012): 94-98. doi: http:// dx.doi.org/10.3968\%2Fj.ibm.1923842820120502.1080.

Kordnaeij, Asadollah., Hossein Askaripoor, and Alireza Bakhshizadeh. "Studying Affecting Factors on Customers' Attitude toward Products with Halal Brand." International Research Journal of Applied Basic Sciences Vol. 4(10) (2013).

Mukhtar, Arshia and Muhammad Mohsin Butt. "Intention to Choose Halal Products: The Role of Religiosity." Journal of Islamic Marketing Vol. 3 Issue 2 (2012): 108120 doi: http://dx.doi.org/10.1108/17590831211232519.

Ngah, Abdul Hafaz., Yuserrie Zainuddin and Ramayah Thurasany. "Barriers and Enablers in Adopting Halal Transportation Services: A Study of Malaysian Halal Manufacturers." International Journal of Business and Management Vol. II No. 2 (2014): 49-70.

Roestamy, Martin. "Consumer Protection Over Meat Consumption in Accordance to Indonesian Legal System." Presented at the International Conference on Consumerism 2013 (ICC 2013). Faculty of Law UKM Malaysia, 2013, pp. 1-10.

Roestamy, Martin. "The Assurance of Halal Product." Presented at the The 2013 Padjajaran International Legal Conference Series, Padjajaran University, Bandung, 2013.

Samori, Zakiah., Amal Hayati Ishak and Nurul Himmah Kassan. "Understanding the Development of Halal Food Standard: Suggestion for Future Research." International Journal of Social Science and Humanity Vol. 4 No. 6 (November 2006): 482-286. doi: http://dx.doi.org/10.7763/IJSSH.2014.V4.403.

Soesilowati, E. S. "Business opportunities for halal products in the global market: Muslim consumer behaviour and halal food consumption." Journal of Indonesian Social Sciences and Humanities Vol. 3 (January 2010): 151-160. halalHalalHalalHalalHalal

HalalhalalhalalHalalSPRING Singapore. Global Halal Food Industry Guide to Taping the Fasat Growing Halal Food Market. Singapore: SPRING Singapore, 2011. 


\section{Websites}

Badan Pusat Statistik. "Jumlah Perusahaan Industri Besar Sedang Menurut Sub Sektor 2008-2013.” http://www.bps.go.id/tab_sub/view.php?tabel=1\&daftar=1\&id_ subyek=09\&notab=2. Accessed 26 January 2015.

Badan Pusat Statistik. “Nilai Ekspor Dan Impor Menurut Golongan SITC, 2010-2013." http: //www.bps.go.id/tab_sub/view.php?kat=2\&tabel=1\&daftar $=1 \&$ id _ subyek=08\&notab=5. Accessed 26 January 2015.

Bisnis.com. "Surplus Daging Impor: Peternak Lokal Tak Berdaya." http://industri. bisnis.com/read/20141120/99/274447/surplus-daging-impor-peternaklokal-tak-berdaya. Accessed 26 January 2015.

Department of Standard Malaysia. "The Official Website of Department of Standards Malaysia." http://www.standardsmalaysia.gov.my/. Accessed January 2015.

LP-POM MUI. "Daftar Lembaga Sertifikasi Halal." http://www.halalmui.org/mui14/ index.php/main/go_to_section/7/36/page/1. Accessed 26 January 2015.

LP-POM MUI. "Recomendation International Workshop: Indonesias Role for Slaugthering Global Halal." http://www.halalmui.org/newMUI/index.php/ main/detil_page/8/538, 2014. Accessed 25 November 2014.

LP-POM MUI. "Rekapitulasi Sertifikat Halal Tingkat Nasional." http://www.halalmui. org/mui14/index.php/main/go_to_section/59/1368/page/1. Accessed 26 January 2015.

Halalhalal

\section{Other}

King Saud University. Alquran Digital 'Ayat'. Version 1.3.2. 